\title{
A comparison of induced and developmental cell death morphologies in lace plant (Aponogeton madagascariensis) leaves
}

\author{
Adrian N Dauphinee, Trevor S Warner and Arunika HLAN Gunawardena*
}

\begin{abstract}
Background: Programmed cell death (PCD) is an important process for the development and maintenance of multicellular eukaryotes. In animals, there are three morphologically distinct cell death types: apoptosis, autophagic cell death, and necrosis. The search for an all-encompassing classification system based on plant cell death morphology continues. The lace plant is a model system for studying PCD as leaf perforations form predictably via this process during development. This study induced death in cells that do not undergo developmental PCD using various degrees and types of stress (heat, salt, acid and base). Cell death was observed via live cell imaging and compared to the developmental PCD pathway.

Results: Morphological similarities between developmental and induced PCD included: disappearance of anthocyanin from the vacuole, increase in vesicle formation, nuclear condensation, and fusing of vesicles containing organelles to the vacuole prior to tonoplast collapse. Plasma membrane retraction was a key feature of developmental PCD but did not occur in all induced modes of cell death.

Conclusions: Regardless of the causal agent in cell death, the vacuole appeared to play a central role in dying cells. The results indicated that within a single system, various types and intensities of stress will influence cell death morphology. In order to establish a plant cell death classification system, future research should combine morphological data with biochemical and molecular data.
\end{abstract}

Keywords: Programmed cell death, Vacuole, Plasma membrane, Morphology, Cell death classification, Developmental PCD, Environmentally induced PCD, Tonoplast, Live cell imaging, Autophagy

\section{Background}

Cell death processes that remove unwanted, infected, or damaged cells have evolved in eukaryotic organisms [1-3]. Traditionally, active cell death regimes have been denoted as programmed cell death (PCD), while cell death that occurs more passively has been called necrosis; however, recent studies call into question the validity of this dichotomy as there is evidence which suggests that necrosis is an active process as well [4]. PCD can be either developmentally regulated or environmentally induced [5], although significant overlap exists in the mechanisms [6]. Cell death traits differ among taxonomic groups and even histological origins within a species $[3,7]$. It is for this reason that efforts have been employed

* Correspondence: arunika.gunawardena@dal.ca

Department of Biology, Dalhousie University, 1355 Oxford Street, Halifax, NS B3H, 4R2, Canada

\section{Biomed Central}

to create cell death classification systems, which have been primarily based on cellular morphology, and more recently, biochemical and molecular data.

In animals, there are three distinct cell death morphology types: apoptosis, autophagic cell death, and necrosis [8]. First coined by Kerr et al. [9], apoptotic morphology is characterized by a reduction of cellular volume, chromatin condensation, nuclear fragmentation, conservation of organelle ultrastructure, retention of plasma membrane (PM) integrity until an advanced stage of the death process, and subsequent formation of apoptotic bodies (Reviewed by Kroemer et al. [8]). Cells that undergo apoptosis do not cause an inflammatory reaction and are engulfed by phagocytes. Autophagic cell death is characterized by a substantial increase in autophagy prior to death [8]. Autophagic cell death in animals typically consists of an increase in autophagosomes (double membrane 
vesicles), which later fuse with lysosomes, and in contrast to apoptosis, there is no chromatin condensation [10]. In animals there exist three types of autophagy: microautophagy, macroautophagy, and chaperone-mediated autophagy, while in plants there are additional forms of autophagy including but not necessarily limited to mega-autophagy, involving collapse of the tonoplast, and internal degradation of chloroplasts [11]. Although autophagy, or "self-eating", is typically a pro-survival or reparatory mechanism, it has, in certain instances, been seen to promote cell death such as in Drosophila salivary glands during metamorphosis (as reviewed by Green [12]). Necrosis is typically associated with cell death induced by intense stressors, and has traditionally been seen as a more passive process. Necrotic morphology has been characterized by an increase in cellular volume, organelle swelling, early PM rupture, and subsequent spilling of intracellular components [10].

Currently, there is a marked lack of consensus over the classification of different plant PCD types. In the year 2000, Fukuda placed plant PCD into three categories based on cytological features including: apoptotic-like cell death, leaf senescence, and PCD where the vacuole plays a central role [7]. According to Fukuda, the morphological hallmark for apoptotic-like cell death is a retraction of the PM from the cell wall and cytoplasmic condensation [7]. Van Doorn and Woltering in 2005 stated that no plant examples conformed to the characteristics of true apoptosis [13]. They suggest that several PCD examples appeared to be autophagic, while many other PCD types fit into neither category [13]. Reape and McCabe in 2008, and furthermore in 2013, built on the apoptotic-like cell death classification $[14,15]$. They discuss that despite true apoptosis not being present in plants, a number of similarities exist, specifically concerning PM retraction, which could be evolutionarily conserved [15]. Van Doorn et al., (2011) suggest there are two forms of plant PCD: vacuolar cell death and necrotic cell death, and that any use of the term apoptosis, or any derivative thereof when discussing plant PCD is a misapplication [16]. According to these authors, vacuolar cell death consists of degradation of the cell by both autophagy-like processes and the release of hydrolases immediately after tonoplast rupture [16]. Additionally, necrotic cell death is assumed to be a type of plant PCD due to the recent reports of internal signalling pathways during necrosis in animal models [16]. Alternatively, van Doorn (2011) later argued that since the vacuole is involved in almost all plant PCD types (including those not falling under the definition of vacuolar cell death), that plant PCD categories should be based on the rupture of the tonoplast in relation to cytoplasmic clearing [17]. Therefore, van Doorn [17] proposed two new categories: autolytic PCD, where rapid cytoplasmic clearing occurs post tonoplast collapse, and non-autolytic PCD, where despite the rupture of the tonoplast, no rapid cytoplasmic clearing occurs. Despite almost 15 years of attempts, well defined, workable definitions for plant PCD types based on morphology are still being developed.

Aponogeton madagascariensis, also known as lace plant, is a freshwater monocot endemic to the streams of Madagascar. Lace plant leaves possess a perforated lamina and are anchored to the corm by petioles with a sheathing base $[18,19]$. This unique perforated leaf morphology has lent to its cultivation by aquarium enthusiasts for over 100 years [18]. Lace plant leaf perforations form via developmentally regulated PCD [20]. The lace plant is an excellent model organism for studying developmentally regulated $\mathrm{PCD}$ because of cell death predictability in window stage leaves (Figure 1A) between longitudinal and transverse veins (Figure 1B). Additionally, the thin, almost transparent leaves facilitate observation via live cell microscopy [5,20-22]. Within an areole, a gradient of PCD can be seen during the window stage of development, which consists of three stages: Non (NPCD; Figure 1C), early (EPCD; Figure 1D) and late PCD (LPCD; Figure 1E) [24].

PCD initiates in the centre of the areole, which is nearly void of pigment as LPCD cells have lost their anthocyanin and the majority of their chlorophyll content (Figure 1E). In LPCD cells, the vacuole swells, displacing the nucleus and cytoplasmic components towards the PM. Subsequent rupture of the tonoplast and release of hydrolytic enzymes occurs, also known as mega-autophagy. Those cells that have lost their anthocyanin, yet still have chlorophyll, are EPCD cells (Figure 1D). Interestingly, the 4-5 cell layers adjacent to the veins do not undergo PCD during leaf perforation are in the NPCD stage (Figure $1 C ;[23]$ ). Unlike cells which undergo PCD, NPCD cells retain their anthocyanin throughout perforation formation (Figure 1C). After the loss of anthocyanin, changes in the chloroplasts occur, resulting in a reduction of chlorophyll. Concurrently, there is an increase in transvacuolar strands (TVS), vesicles, vacuolar aggregates, and perinuclear accumulation of both chloroplasts and mitochondria [22].

The objective of our study is to elucidate cell death morphology of different degrees and types of stressors to contribute to the formation of a plant cell death classification system. Cell death due to extreme stressors typically causes a necrotic morphology. Conversely, cell death due to mild stressors occurs more gradually and usually displays morphology typical of developmental PCD. We assume this as a hypothesis for the present work. This study utilized the unique lace plant model system to compare various environmentally induced cell death morphologies in NPCD cells to the typical developmentally regulated PCD morphology described during perforation formation using live cell imaging techniques. Recognizing how cell death morphology and the vacuole 


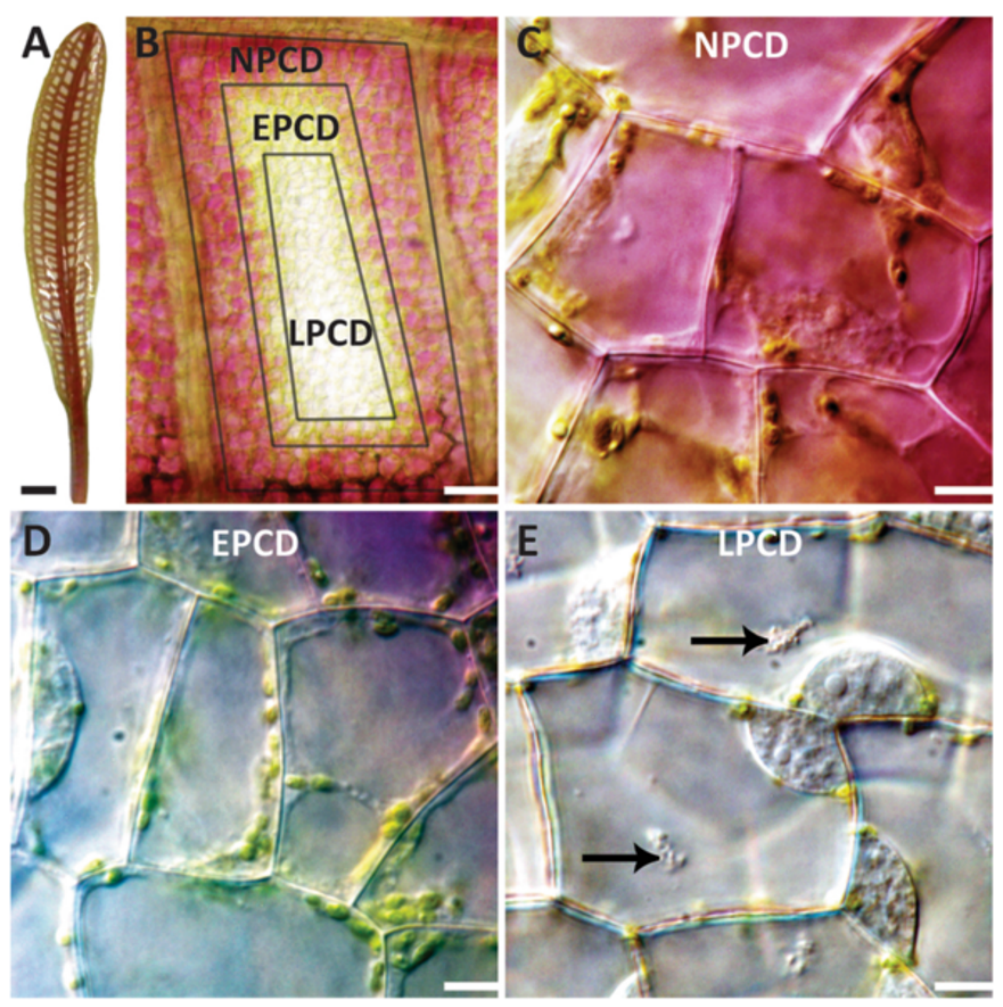

Figure 1 Developmental PCD during perforation formation in the lace plant. (A) Lace plant with window formation stage leaf. (B) Individual areole between longitudinal and transverse veins showing borders of all three cell types: NPCD, EPCD, and LPCD cells. (C) NPCD cells, pink colouration is due to anthocyanin localized to vacuoles in the underlying mesophyll cells. (D) EPCD cells, showing disappearance of anthocyanin but retention of chloroplasts. (E) LPCD cells, with few remaining chloroplasts. Large aggregates are present in the central vacuole (black arrows). Scale bars: $\mathrm{A}=3 \mathrm{~mm}, \mathrm{~B}=150 \mu \mathrm{m}, \mathrm{C}-\mathrm{E}=15 \mu \mathrm{m}$.

and PM in particular vary in response to different modes of induction within a single system will provide a better understanding of the intracellular dynamics of cell death.

\section{Results}

Developmental PCD and the framework for comparison Leaf perforations in lace plant form via a type of developmentally regulated PCD. The morphological features that accompany this transition were defined by Wertman et al. [22] (described in the background), and were used for comparison to the induced treatments in this study (Additional file 1; Table 1). Untreated NPCD cells (which do not undergo developmental PCD during perforation formation) showed no definitive signs of cell death within a $6 \mathrm{~h}$ observation and were used as experimental controls to ensure that treatments triggered cell death (Additional file 2). The time for cell death to occur is represented as the mean \pm standard deviation and spans from the moment a given treatment was applied until tonoplast collapse or PM retraction were observed. All videos, regardless of original acquisition times have been standardized to a length of 1 min which is responsible for the differences in playback speeds.

\section{Heat shock experiments}

Leaf pieces were treated for $10 \mathrm{mins}$ at $45^{\circ} \mathrm{C}, 55^{\circ} \mathrm{C}, 65^{\circ} \mathrm{C}$, and then observed microscopically. No cell death occurred within $6 \mathrm{~h}$ in the $45^{\circ} \mathrm{C}$ treatment (Figure 2A,B). The cell colouration, and the morphology of the nucleus, the chloroplasts, the vacuole, vesicles, and the PM were not observed to have changed within the $6 \mathrm{~h}$ (Figure 2A,B; Additional file 3). The $55^{\circ} \mathrm{C}$ treatment caused all cells to die in $5.57 \pm 0.21 \mathrm{~h}$ (Figure 2C,D). Cells showed nearly slight anthocyanin disappearance shortly after the heat treatment (Figure 2C; Additional file 3). There appeared to be dramatic nuclear condensation (Additional file 4). Chloroplast abundance and shape did not appear to change (Figure 2C,D). Noticeably, there was an increase in the number of vesicles (Additional file 4). As vacuolar swelling continued, some of the vesicles appeared to fuse with the central vacuole immediately prior to tonoplast permeabilization (Additional file 4). PM retraction occurred shortly after the tonoplast collapsed (Figure 2D; Additional file 4).

Leaf pieces that were treated at $65^{\circ} \mathrm{C}$ had no living cells by the time they were examined under the microscope (approximately 5 mins after treatment). Therefore, 
Table 1 A comparison of lace plant cell death morphologies

\begin{tabular}{|c|c|c|c|c|c|c|c|c|}
\hline \multirow[t]{3}{*}{ Morphological characteristics } & \multirow{3}{*}{$\begin{array}{l}\text { Developmental } \\
\text { Leaf perforation }\end{array}$} & \multicolumn{7}{|c|}{ Environmentally induced cell death } \\
\hline & & \multirow{2}{*}{$\begin{array}{l}\text { Heat } \\
55^{\circ} \mathrm{C}\end{array}$} & \multicolumn{2}{|l|}{$\mathrm{NaCl}$} & \multicolumn{2}{|l|}{ Acid (HCl) } & \multicolumn{2}{|l|}{ Base (NaOH) } \\
\hline & & & $400 \mathrm{mM}$ & $2 M$ & $3 \mathrm{mM}$ & $12 \mathrm{M}$ & $30 \mathrm{mM}$ & $1 \mathrm{M}$ \\
\hline Anthocyanin disappearance & + & + & + & + & + & - & + & + \\
\hline Perinuclear chloroplast formation & + & - & - & - & - & - & - & - \\
\hline Vesicle formation & + & + & + & + & + & - & + & - \\
\hline Vacuolar swelling & + & + & + & + & + & - & + & + \\
\hline Nuclear condensation & + & + & + & + & + & + & - & - \\
\hline Cessation of cytoplasmic streaming & + & + & + & + & + & + & + & + \\
\hline Tonoplast collapse & + & + & + & + & + & + & + & + \\
\hline $\mathrm{PM}$ retraction at death & + & + & - & + & - & + & - & - \\
\hline $\begin{array}{l}\text { Mean total time for death } \\
\text { ( } \geq 3 \text {; time } \pm \text { st. dev.) }\end{array}$ & $\sim 48 \mathrm{~h}$ & $5.57 \pm 0.21 \mathrm{~h}$ & $5.32 \pm 0.63 h$ & $4.25 \pm 0.38 h$ & $4.02 \pm 1.2 \mathrm{~h}$ & $3.48 \pm 1.67 \mathrm{~min}$ & $33.72 \pm 5.44 \mathrm{~min}$ & $49 \pm 5.3 \mathrm{~s}$ \\
\hline
\end{tabular}

Morphologies of induced cell death (as observed in additional files) compared to developmental PCD during perforation formation (as delineated by Wertman et al. [22]).

Note: Time for death in the environmentally induced categories spans from the moment of treatment application until collapse of the tonoplast and PM retraction when possible. 

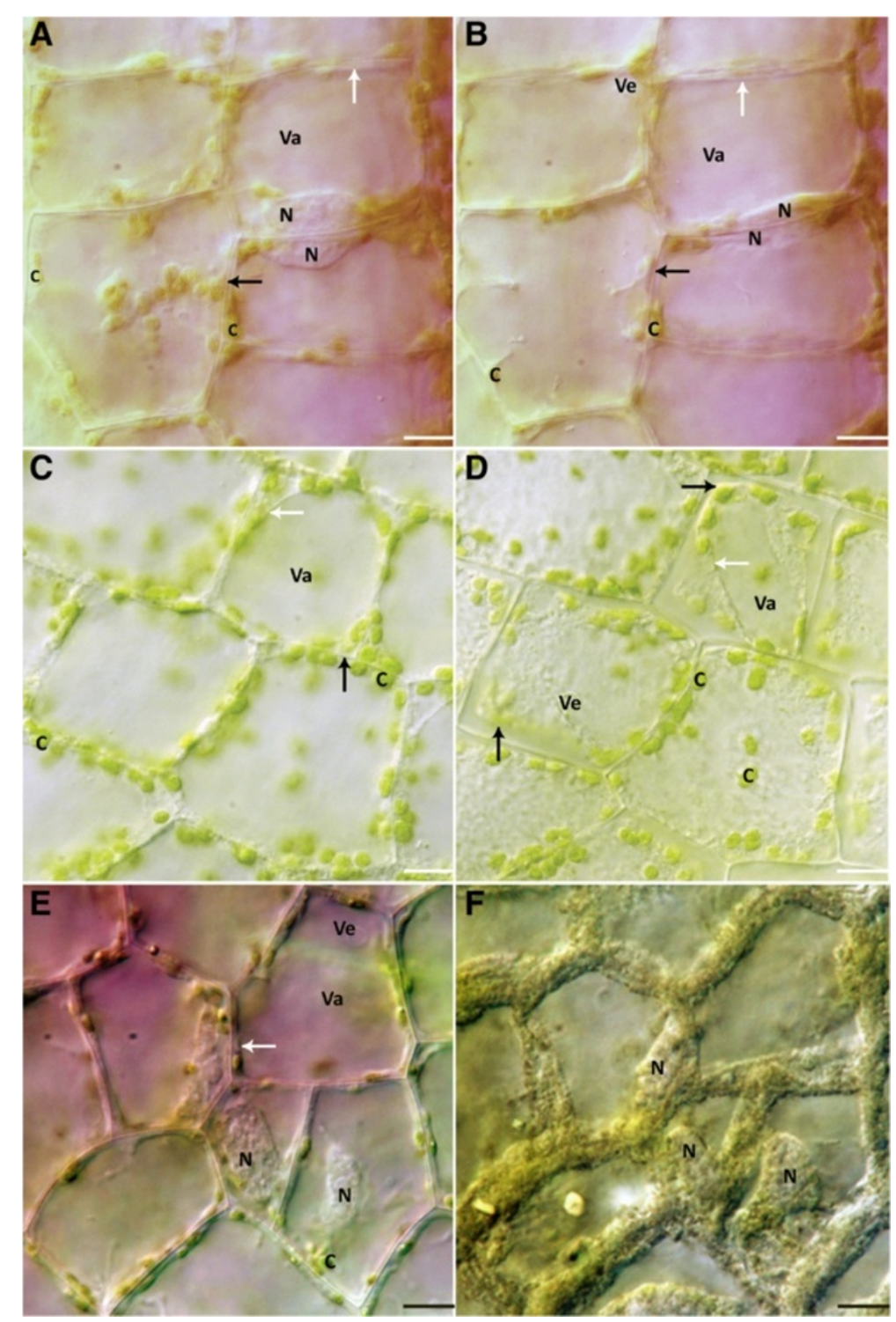

Figure 2 NPCD cells after 10 min heat shock treatments. (A) Cells at $0 \mathrm{~h}$ after $45^{\circ} \mathrm{C}$ treatment. (B) Cells at $6 \mathrm{~h}$ after $45^{\circ} \mathrm{C}$ treatment. Note that tonoplast and PM appears intact. (C) Cells at $0 \mathrm{~h}$ after $55^{\circ} \mathrm{C}$ treatment. Anthocyanin disappearance is evident. (D) Cells at $6 \mathrm{~h}$ after $55^{\circ} \mathrm{C}$ heat shock treatment. Vesicle formation appears throughout cells. (E) NPCD cells before $65^{\circ} \mathrm{C}$ treatment. (F) NPCD cells after $65^{\circ} \mathrm{C}$ treatment with disapearance of anthocyanin from the central vacuole. Cellular debris at the periphery of the cells had taken has a textured appearance. (A-D) $\mathrm{N}$ - nucleus, C-chloroplast, Va- vacuole, Ve- vesicle, white arrow-tonoplast, black arrow- PM. Scale bars: A-D = $15 \mu \mathrm{m}$.

images were collected before and after the heat shock treatment, respectively (Figure 2E,F). The cells exposed to this treatment underwent a change in colour from pink-purple to clearing (Figure 2E,F). The dramatic discolouration and change in the appearance of intracellular components made organelle identification difficult. Nevertheless, the comparison between images before and after the heat treatment shows a resulting granular appearance, along the margins of the cell, post-treatment (Figure 2E,F).

\section{Sodium chloride experiments}

Leaf pieces were mounted in $100 \mathrm{mM}, 400 \mathrm{mM}$ and $2 \mathrm{M}$ $\mathrm{NaCl}$ solutions and observed for $6 \mathrm{~h}$ (or until cell death). Leaf pieces treated with $100 \mathrm{mM} \mathrm{NaCl}$, showed no change in cell colouration, cytoplasmic streaming, as well as nuclear and PM dynamics within the $6 \mathrm{~h}$ (Figure 3A,B; Additional file 5). Chloroplasts had a wrinkled appearance near the end of the observation (Additional file 5). Additionally, the size of the vacuole appeared to increase (Figure 3A,B; Additional file 4). Cells did not die within the $6 \mathrm{~h}$ treatment. 

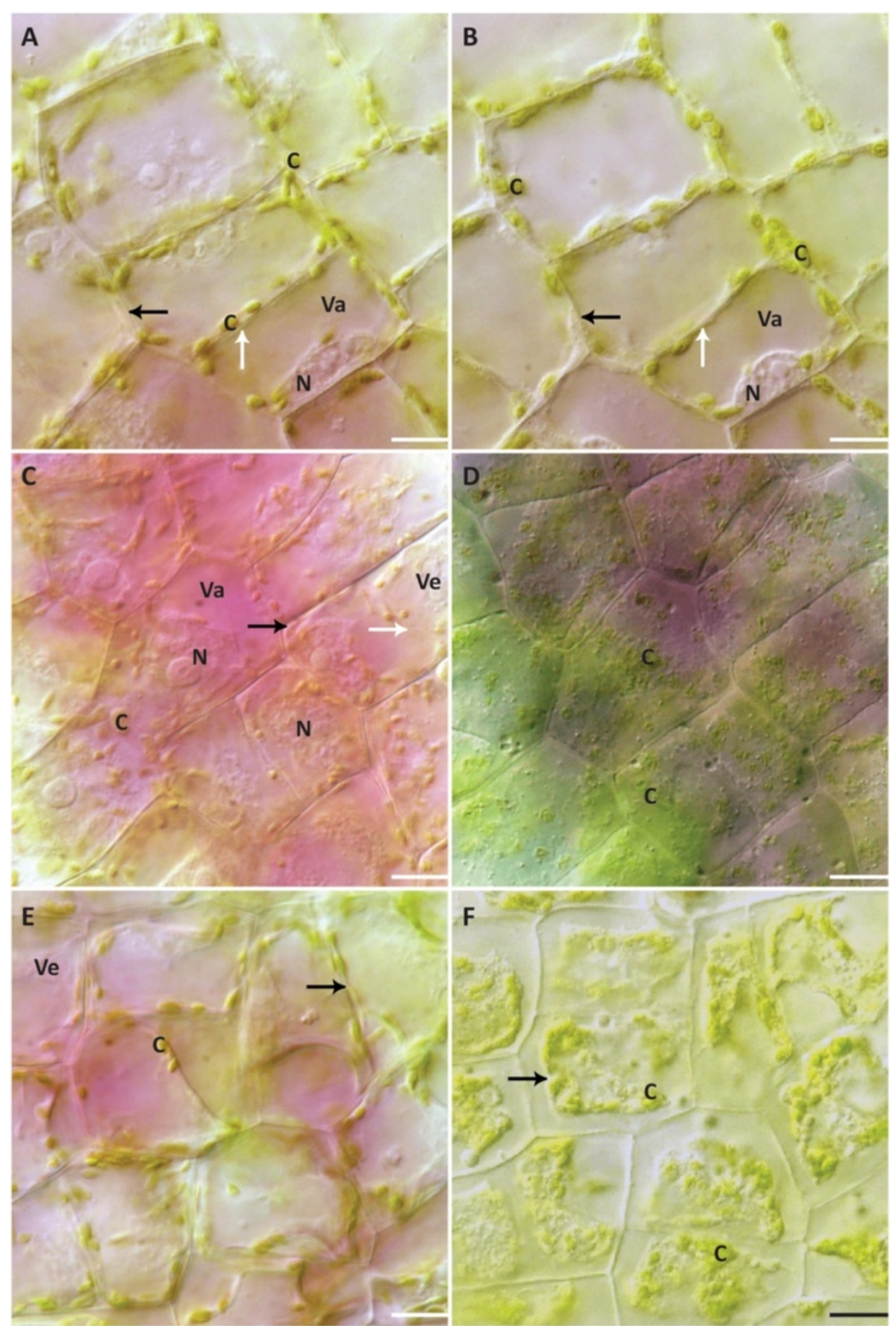

Figure $3 \mathrm{NaCl}$ treatment cell morphology. (A) NPCD cells at $0 \mathrm{~h}$ of the $100 \mathrm{mM} \mathrm{NaCl}$ treatment. (B) NPCD cells at $6 \mathrm{~h}$ of $100 \mathrm{mM} \mathrm{NaCl}$ treatment. Chloroplasts have taken on a 'wrinkled' appearance. (C) NCPD cells at $0 \mathrm{~h}$ of $400 \mathrm{mM} \mathrm{NaCl}$ treatment. (D) Dead NPCD cells following $400 \mathrm{mM} \mathrm{NaCl}$ treatment. There is no PM retraction at cell death. (E) NPCD cells at 0 h of $2 \mathrm{M} \mathrm{NaCl}$ treatment. (F) Dead NPCD cells following $2 \mathrm{M}$ $\mathrm{NaCl}$ treatment. Note that PM retraction occurs. (A-F) N- nucleus, C- chloroplast, Va- vacuole, Ve- vesicle, white arrow- tonoplast, black arrow- PM. Scale bars: A-F $=15 \mu \mathrm{m}$.

Leaf pieces treated with $400 \mathrm{mM} \mathrm{NaCl}$, cell colouration appeared grey until turning greener at the moment of cell death after $5.32 \pm 0.63 \mathrm{~h}$ (Figure 3C,D). Immediately following the start of treatment, plasmolysis occurs as evidenced by the PM peeling away from the cell wall, with filamentous structures visible between the PM and the cell wall (Additional file 6). The nucleus appeared to condense, and the chloroplasts were swollen and wrinkled later in the process (Figure 3C,D). Vesicle formation occurred in the cell, as well as a cessation of 

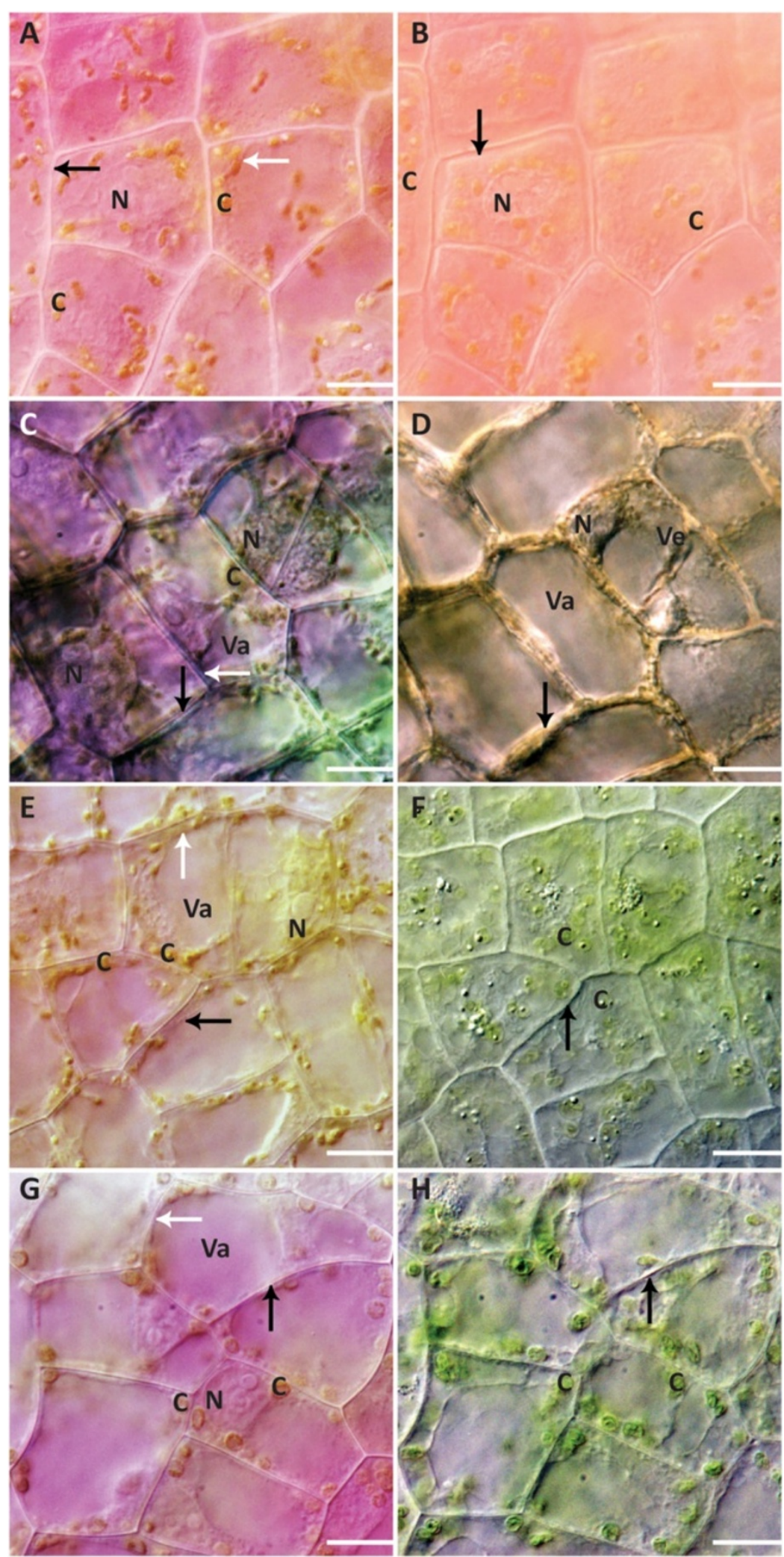

Figure 4 (See legend on next page.) 
(See figure on previous page.)

Figure 4 Acid and alkaline treatment cell morphology. (A) NPCD cells at $0 \mathrm{~h}$ for the $12 \mathrm{M} \mathrm{HCl}$ treatment. (B) NPCD cells at cell death after the $12 \mathrm{M} \mathrm{HCl}$ treatment. Nuclear condensation was evident. PM retraction was observed. Anthocyanin colouration remains, although a slight colour change occurs. (C) NPCD cells at $0 \mathrm{~h}$ for the $3 \mathrm{mM} \mathrm{HCl}$ treatment. (D) NPCD cells after death induced by $3 \mathrm{mM} \mathrm{HCl}$. Anthocyanin disappearance occurs throughout treatment. (E) NPCD cells at $0 \mathrm{~h}$ for the $30 \mathrm{mM} \mathrm{NaOH}$ treatment. (F) NPCD cells at cell death for the $30 \mathrm{mM}$ $\mathrm{NaOH}$ treatment. No retraction of the PM occurs. Note the swollen and 'wrinkled' appearance of the chloroplasts. (G) NPCD cells at $0 \mathrm{~h}$ for the $1 \mathrm{M} \mathrm{NaOH}$ treatment. (H) NPCD cells after death for the $1 \mathrm{M} \mathrm{NaOH}$ treatment. No PM retraction occurs. Note the swollen and 'wrinkled' appearance of the chloroplasts. (A-H) N- nucleus, C- chloroplast, Va- vacuole, Ve- vesicle, white arrow- tonoplast, black arrow- PM. Scale bars: $\mathrm{A}-\mathrm{H}=25 \mu \mathrm{m}$.

cytoplasmic streaming (Figure 3C,D). Vacuolar swelling occurred before the vesicles lysed and the tonoplast permeabilized (Figure 3C,D; Additional file 6). There was no retraction of the PM once the tonoplast collapsed (Additional file 6). The cell colouration that changed from pink to green occurred while the vesicles lysed (Additional file 6).

For leaf pieces treated with $2 \mathrm{M} \mathrm{NaCl}$, cell colouration changed gradually and eventually became green as cell death progressed over a $4.25 \pm 0.38 \mathrm{~h}$ timeframe (Figure 3E,F). After application of the treatment, the PM peeled away from the cell wall. Some filamentous structures connecting the PM to the cell wall were observed, but very few in comparison to the $400 \mathrm{mM} \mathrm{NaCl}$ treatment. There was very little cytoplasmic movement, and later in the cell death some vesicles were observed. Vacuolar swelling and tonoplast rupture were observed. Late in the death process, numerous spherical opaque bodies of various sizes were prominent and could be seen merging together (Figure 3E,F; Additional file 7). As the cells died, these spherical bodies shrank and disappeared as PM retraction occurred (Additional file 7).

\section{Acid and base experiments}

The acid and base concentrations chosen for the experiments represent the most severe that were feasible (12 M HCl, $1 \mathrm{M} \mathrm{NaOH}$ ), and those least severe but still triggering cell death within $6 \mathrm{~h}(3 \mathrm{mM} \mathrm{HCl}, 30 \mathrm{mM}$ $\mathrm{NaOH}$ ). Leaf pieces were treated with $12 \mathrm{M} \mathrm{HCl}, 3 \mathrm{mM}$ $\mathrm{HCl}, 30 \mathrm{mM} \mathrm{NaOH}$, and $1 \mathrm{M} \mathrm{NaOH}$ solutions and observed as mentioned above. In the $12 \mathrm{M} \mathrm{HCl}$ solution, the mean time for cell death was $3.48 \pm 1.67 \mathrm{~min}$. The cell colouration immediately changed, with cells appearing bright pink (Additional file 8). Immediately before nuclear condensation, the nucleoli appeared to swell (Additional file 8). Nuclear, chloroplast, and vacuole condensation appeared to occur simultaneously (Additional file 8). No differences in vesicle formation were observed. Tonoplast collapse occurred before retraction of the PM from the cell (Figure 4A,B; Additional file 8).

The cells of leaf pieces treated with $3 \mathrm{mM} \mathrm{HCl}$ solution died $4.02 \pm 1.02 \mathrm{~h}$ following treatment. Increasing translucency of the cell accompanied by loss of colour was observed (Figure 4C,D; Additional file 9). Swelling of the vacuole occurred concurrently with vesicle formation, and the condensation of the nucleus and chloroplasts occurred immediately before cell death (Additional file 9). There was an evident increase in aggregate number and size, in addition to an increase in TVS throughout the treatment (Additional file 9). In previous studies, these aggregates were found to contain organelles such as chloroplasts and mitochondria [22]. Tonoplast collapse was evident in the later stages of death and the PM did not retract (Figure 4C,D; Additional file 9).

For leaf pieces treated with a $30 \mathrm{mM} \mathrm{NaOH}$ solution, the mean time for cell death was $33.72 \pm 5.44 \mathrm{~min}$. Treatment led to a change in cell colouration from pink to blue/green prior to clearing (Figure 4E,F; Additional file 10). Nuclear displacement occurred progressively throughout the treatment (Additional file 10). Throughout the death process, there was an increase in the number of vesicles (Additional file 10). At the time of cellular death, chloroplasts appeared swollen (Figure 4F). The size of the vesicles appeared to be larger than those seen in other induced treatments (Additional file 10). In tandem with the increase in vesiculation was an apparent increase in the size of the vacuole (Additional file 10). Collapse of the tonoplast was immediately preceded by either collapse of vesicle membranes, or fusion with the central vacuole (Additional file 10). Inside both the vesicles and the vacuole, precipitates appeared immediately before collapse (Additional file 10). Simultaneous with the tonoplast collapse was dramatic swelling of the chloroplasts (Additional file 10). There was no retraction of the PM, however, it was not believed to have remained intact (Figure 4F; Additional file 10). Treatment of lace plant leaf sheath tissue with $30 \mathrm{mM}$ $\mathrm{NaOH}$ showed the same cell death features as reported for NPCD cells, but also allowed for a clearer view of vesicles within the cell compared to leaf tissue (Additional file 11). Aggregates, and intracellular components, including whole organelles like chloroplasts, were observed to enter the vesicles and fuse with the central vacuole immediately prior to cell death (Additional file 11).

For leaf pieces treated with a $1 \mathrm{M} \mathrm{NaOH}$ solution, the mean time for induced cell death was $49 \pm 5.3 \mathrm{~s}$. Cell colouration changed from pink to blue and then to green post cell death (Additional file 12). The nucleus 
disappeared immediately before cell death (Figure 4G,H; Additional file 12). Chloroplasts swelled either immediately before or during vesicular and vacuolar collapse (Figure 4H; Additional file 12). Vesicular collapse either preceded or occurred in tandem with vacuolar collapse (Additional file 12). The PM did not retract and appeared to lose its integrity (Figure 4G,H; Additional file 12).

\section{Discussion}

Heat shock treatments have been found to alter cell metabolism, disrupt mitochondria, and result in an increase in ROS $[23,25]$. Depending on the severity, heat shock will result in cell death. In the $55^{\circ} \mathrm{C}$ treatment, anthocyanin disappearance was apparent immediately after treatment. It is suspected by the authors, that a spike in ROS may have played a role in anthocyanin disappearance, although anthocyanin is also a heat sensitive pigment [26]. In addition to anthocyanin disappearance, there was a marked increase in the number of vesicles within the cell. The characteristic increase in vesicles, the appearance of organelles in the vacuole, and an increased volume of the central vacuole, up until tonoplast collapse, provides evidence for both macro-, and mega-autophagy. The retraction of the PM from the cell wall after tonoplast collapse resembles the PM retraction observed during lace plant developmental PCD, however the ultrastructure of the PM at this point was not investigated. Although, it should be noted that the cell corpse in developmental PCD exhibits a more condensed morphology in comparison. Similarly, PM shrinkage has been shown in heat shock experiments using lace plant protoplasts [23]. Surprisingly, the protoplasts were less susceptible to heat shock at $55^{\circ} \mathrm{C}$ than the in situ cells in our experiment, with the protoplasts undergoing $\mathrm{PCD}$ after 20 min while the in situ cells underwent PCD after $10 \mathrm{~min}$. The severity of the $65^{\circ} \mathrm{C}$ treatment resulted in cell death before completion of the treatment. The $65^{\circ}$ $\mathrm{C}$ cell death morphology appeared remarkably different compared to the $55^{\circ} \mathrm{C}$ treatment, lacking PM retraction and with a loss of chlorophyll from the chloroplasts. The textured appearance along the periphery of the cell is believed to be the remains of cellular debris. Membranes within the cell are not believed to have retained their integrity. The subsequent morphology of the $65^{\circ} \mathrm{C}$ treatment is characteristic of what is commonly considered necrotic cell death $[15,16]$.

In the $100 \mathrm{mM} \mathrm{NaCl}$ treatment, there was a dramatic slowing in cytoplasmic streaming. Sodium chloride stress has been implicated in an increase in cytoplasmic $\mathrm{Ca}^{2+}$, which can arrest cytoplasmic streaming, by $\mathrm{Na}^{+}$displacing $\mathrm{Ca}^{2+}$ from the PM, and from liberating $\mathrm{Ca}^{2+}$ from internal stores [27]. However, there is little research that assesses the effects of salinity on cytoplasmic streaming [28]. In the $100 \mathrm{mM}$ and $400 \mathrm{mM} \mathrm{NaCl}$ treatments, the chloroplasts took on a wrinkled appearance. This wrinkled effect on chloroplast ultrastructure has similarly been observed in TEM images of tomato cells grown in a medium containing $100 \mathrm{mM} \mathrm{NaCl} \mathrm{[29].} \mathrm{Chloroplasts} \mathrm{appeared}$ swollen in the $400 \mathrm{mM} \mathrm{NaCl}$ treatment, but this effect was not observed in the $2 \mathrm{M} \mathrm{NaCl}$ experiments. In potato cultivars, electron microscopy showed that although the structural integrity of cells appeared intact, the chloroplasts appeared swollen when plants were irrigated with $100 \mathrm{mM}$, and $200 \mathrm{mM} \mathrm{NaCl}$ solution, respectively [30]. Swollen chloroplasts have also been seen in wheat and sweet potato leaves under salt stress [30,31].

Interestingly, the vacuole appeared to increase in size in the $100 \mathrm{mM} \mathrm{NaCl}$ treatment, which occurs similarly in LPCD cells during leaf perforation developmental PCD. This rapid increase in vacuole size, in response to saline conditions, has been demonstrated in suspensioncultured of mangrove cells and barley root meristematic cells [32]. $\mathrm{Na}^{+}$accumulation in the central vacuole and subsequent increase in vacuolar volumes has been shown to be an active process and is believed to be one strategy employed by the cell in response to salt stress [32]. Vesicle formation occurred in the $400 \mathrm{mM}$ and $2 \mathrm{M} \mathrm{NaCl}$ treatments, suggesting an increase in macro-autophagy, perhaps to recycle damaged intracellular components [33]. High salt solutions have been shown to elicit autophagy in Arabidopsis thaliana by up-regulating autophagy related genes [33].The initial retraction of the PM from the cell wall in the $400 \mathrm{mM}$ and $2 \mathrm{M} \mathrm{NaCl}$ treatments, in contrast to the late-stage PM retraction seen in developmental PCD, is plasmolysis and is due to changes in osmotic pressure. The filamentous structures between the PM and the cell wall observed during plasmolysis are speculated to be hechtian strands ([34]; Additional files 6, and 7). Interestingly, there were many more of these strands in the $400 \mathrm{mM} \mathrm{NaCal}$ compared to the $2 \mathrm{M} \mathrm{NaCl}$ treatment. At the final stages of death there was a contrast between these two treatments; cell treated with $400 \mathrm{mM} \mathrm{NaCl}$ exhibited tonoplast rupture and no PM retraction, whereas the $2 \mathrm{M} \mathrm{NaCl}$ treatment had a significant PM retraction. The authors speculate that the numerous strands connecting to the cell wall in the $400 \mathrm{mM} \mathrm{NaCl}$ treatment group played a role in negating the PM retraction which occurred after treatment at the higher concentration.

The most striking characteristic of the $12 \mathrm{M} \mathrm{HCl}$ treatment is the surprising dramatic retraction of the PM from the cell wall. The PM retraction in the $12 \mathrm{M}$ $\mathrm{HCl}$ treatment resembled PM retraction seen at the end of developmentally regulated PCD in lace plant perforation formation. Although this retraction appears to be morphologically similar, this cell death lies in contrast to PCD in perforation formation, which typically takes several days. The cell death process in the $12 \mathrm{M} \mathrm{HCl}$ treatment was rapid and although the ultrastructural changes 
to the PM are unknown, the authors suspect this is a passive process. In the $3 \mathrm{mM} \mathrm{HCl}$ treatment, cytoplasmic streaming slowed, which may have been a result of either a change in cytoplasmic $\mathrm{pH}$ or an increase in cytosolic $\mathrm{Ca}^{2+}$. The vacuole swelled extensively, which may have been a cellular response to extracellular acidity by increasing the volume of the vacuole, as it is generally more acidic than the cytoplasm under normal conditions. The swelling of the vacuole in this treatment resembled swelling in LPCD cells during developmental PCD. The observation of vesicles was similar to the salt stress treatments, and may be indicative of an increase in macroautophagy. Cell death occurred with the permeabilization of the tonoplast. In the $30 \mathrm{mM} \mathrm{NaOH}$ treatment, there was a considerable increase in vesicles compared to other treatments, which may also indicate an increase in macroautophagy. The change in colour of the vacuole from pink to blue/green immediately before cell death suggests that the vacuolar $\mathrm{pH}$ was dramatically raised to near alkalinity as anthocyanin's visible colour shifts.

Comparison between induced cell death and its developmental counterpart revealed that there are several common characteristics, including cessation of cytoplasmic streaming and tonoplast collapse (Table 1). Vacuolar dynamics appear to be consistent among the developmental and induced cell death videos (Table 1), and occupying the majority of a plant cell, it is likely to make a substantial contribution to cell death processes. Perinuclear chloroplast formations only occurred during developmental cell death. Likewise, the $12 \mathrm{M} \mathrm{HCl}$ treatment was the only cell death without anthocyanin disappearance, which is likely due to the response of the pigment to the low $\mathrm{pH}$ of the solution. In the $\mathrm{NaOH}$ treatments, nuclear condensation was not observed, in contrast to all other cell death types. Vesicle formation was a common characteristic of all cell death types except those that resulted in very rapid cell death, such as the $12 \mathrm{M} \mathrm{HCL}$ and $1 \mathrm{M} \mathrm{NaOH}$ treatments. PM retraction was seen in perforation formation, the $55^{\circ} \mathrm{C}, 2 \mathrm{M} \mathrm{NaCl}$ and $12 \mathrm{M} \mathrm{HCl}$ treatment groups. Interestingly, in all cases where cell death was observed, the vacuole played a central role, specifically seen with tonoplast collapse occurring in all cell death types. The results of this comparative study are summarized in Table 1.

In animal cells, there exists a morphologic classification system of cell death types, with three categories: apoptosis, autophagic cell death, and necrosis. Among the most apopotic-like characteristic seen in the lace plant is retraction of the PM due to a reduction in cell volume observed during leaf perforation developmental PCD. A similar morphology can be seen in the $55^{\circ} \mathrm{C}$ treatment, $2 \mathrm{M} \mathrm{NaCl}$ and the $12 \mathrm{M} \mathrm{HCl}$ treatment. Regarding autophagic cell death, an increase in vacuolar swelling and vesicle formation was observed in heat, salt, and most $\mathrm{pH}$ treatments. Notably, an increase in vesicles was not observed in the most extreme $\mathrm{pH}$ treatments (12 M HCl, $1 \mathrm{M} \mathrm{NaOH}$ ). In most cell death morphologies induced by less severe stressors, such as in $30 \mathrm{mM}$ $\mathrm{NaOH}$ treatment in leaf sheath tissue, whole organelles encapsulated by a vesicle were seen to fuse with the vacuole prior to tonoplast collapse. Recently, a dual role of autophagy as either an initiator of PCD during the HR (hypersensitive response), or a downstream executioner during developmental PCD has been proposed by Minina et al. [36]. The current authors believe that the examples of autophagy shown here are acting downstream, perhaps through the activation of some components similar to the lace plant leaf perforation developmental pathway. Interestingly, the high number of spherical opaque bodies which formed in the $2 \mathrm{M} \mathrm{NaCl}$ treatment fused with others that were in close proximity, and either disappeared or shrunk before PM retraction and cell death, but more research is needed to determine their composition and function.

Necrotic features such as early rupture of the PM, were typically seen in the most extreme treatments. A reduction of cellular volume, along with the active retraction of the PM is typically associated with a slower, more internally regulated form of cell death; however, PM retraction was seen in the most extreme acid treatment $(12 \mathrm{M} \mathrm{HCl})$ and took place within minutes. While the $\mathrm{PM}$ retractions observed in the $55^{\circ} \mathrm{C}$ and $2 \mathrm{M} \mathrm{NaCl}$ treatments were morphologically similar to the $12 \mathrm{M}$ $\mathrm{HCl}$ treatment, the timeframe for cell death to occur was much longer in comparison. Considering the relatively slow timeframe for cell death from the $55^{\circ} \mathrm{C}$ and $2 \mathrm{M} \mathrm{NaCl}$ treatments $(5.57 \pm 0.21 \mathrm{~h}$ and $4.25 \pm 0.38 \mathrm{~h}$, respectively), the authors hypothesize that the PM retraction is an active process, whereas the $12 \mathrm{M} \mathrm{HCl}$ treatment represents a necrotic collapse. Further investigation is required, however, to determine whether or not the various induced cell death morphologies shown here are forms of PCD.

In 2000, Fukuda proposed the existence of three PCD categories in plants: apoptotic-like, leaf senescence, and one in which the vacuole plays a central role [7]. Since then, there have been several proposed classification systems for plant PCD, but currently none are unanimously accepted. Proposed classifications have often centered on characteristics of a particular organelle, notably the vacuole, or PM. The PM is commonly used due to its conspicuous appearance when retracted from the cell wall. This retraction, along with a reduction of cellular volume are characteristics present in apoptosis but absent in necrosis in animal models. Emphasis on the vacuole is likely due to its expansive nature in plant cells, often occupying up to $90 \%$ of cellular volume 
which is unlike any autolytic organelle found in animal cells. Also, the vacuole is known for its autolytic properties, participating in cellular processes such as autophagy, which are associated to cell death events. Macro-autophagy occurs when cellular components are sequestered to the vacuole via double membrane vesicles. Vacuolar swelling followed by tonoplast collapse, known as mega-autophagy, is common in plant cell death processes, as was observed in this study. It is very possible that future cell death classifications will center on the role of the vacuole in plant cell death, as has been seen in previous classification proposals. Our data indicates that individual stressors typically result in different cell death morphologies amongst differing stressor intensities, despite being within a single system. Other researchers are encouraged to consider the means by which induced PCD studies are carried out. Although the experiments in this paper used isolated stressors, it has been found that more damage occurs to plants when multiple stressors occur simultaneously [35], and therefore it may be considered that treatments should replicate combined stressors that would occur naturally.

\section{Conclusions}

Lace plant (A. madagascariensis) is an ideal model organism for studying both developmental PCD and induced cell death, specifically due to its thin, near-transparent leaves which are suitable for live-cell microscopy. Using live-cell imaging, similarities and dissimilarities were demarcated among the induced treatments and developmental lace plant PCD. Cell death was successfully induced with physical and chemical stressors including heat shock, $\mathrm{NaCl}, \mathrm{HCl}$ and $\mathrm{NaOH}$. Although there were significant differences among the treatments, the vacuole played a central role as mega-autophagy was present in all forms of cell death that were observed. This study illuminates the variability of cell death morphology using different stressors and the authors believe that morphological data, though important should, be coupled with biochemical and molecular data before it can significantly contribute toward the formation of a cell death classification system in plants.

\section{Methods}

\section{Aquarium grown plants}

Aponogeton madagascariensis plants were grown in three aquariums containing freshwater which was supplemented on a weekly basis with: $1 \mathrm{mg} / \mathrm{L}$ monopotassium phosphate, $10 \mathrm{mg} / \mathrm{L}$ potassium nitrate and $3 \mathrm{mg} / \mathrm{L} \mathrm{CSM}+\mathrm{B}$ plantex (Aquarium Fertilizers, Napa, California, USA). Aquarium light intensity was approximately $125 \mu \mathrm{mol} \mathrm{m} \mathrm{m}^{-2} \mathrm{~s}^{-1}$, which was produced from an aqua glow T8 fluorescent light bulb (Hagen, Montréal, Québec, Canada). The aquariums were maintained on a $12 \mathrm{~h}$ light/dark cycle and kept in a room maintained at $24^{\circ} \mathrm{C}$.

\section{Tissue preparation, experimental design, \& control treatment}

Experimental lace plant tissue was derived from window stage leaves and utilized NPCD cells, which would not undergo developmental PCD in perforation formation. Leaves were removed from the plant at the petiole and rinsed in $\mathrm{dH}_{2} \mathrm{O}$. The midrib was excised and the subsequent tissue was sectioned into approximate $5 \mathrm{~mm}^{2}$ pieces. Before treatments, tissue pieces were maintained in $\mathrm{dH}_{2} \mathrm{O}$ with a 6.7-7.0 $\mathrm{pH}$ range at ambient temperature. All tissue was taken from a leaf the same day as the experiment. A tissue piece was placed on a microscope slide and the appropriate solution was added to the slide and then covered and sealed with VALAP (paraffin wax, lanolin, petroleum jelly mixture in a 2:1:1 ratio). There was a minimum of three independent replicates for each experiment with tissue derived from different leaves. Experiments ran for $6 \mathrm{~h}$ or until cell death occurred, which was determined by either tonoplast collapse or PM retraction. For all treatments, various levels of intensity for each stressor were optimized. All treatments presented here were also tested on whole leaves using the custom slide method of Wertman et al. [22] to ensure that the same cell death morphologies occurred in a whole organ and so comparisons could be drawn to the previously described lace plant developmental PCD pathway. This study utilized leaf sections to obtain higher resolution videos and due to logistical constraints when applying the extreme acid and base treatments at the microscope, which was necessary as cell death occurred rapidly. Controls were mounted in $\mathrm{dH}_{2} \mathrm{O}$, at ambient temperature. The solution was first placed on the mounted tissue to create a wet mount and then the cover slide was sealed with VALAP.

\section{Heat treatments}

A water bath (VWR International, Radnor, Pennsylvania, USA) was set to the desired temperature, and filled with water. A beaker filled with $\mathrm{dH}_{2} \mathrm{O}$ was placed into the centre of the water bath. Once the set temperature $\left(45^{\circ} \mathrm{C}, 55^{\circ} \mathrm{C}\right.$, or $65^{\circ} \mathrm{C}$ ) was attained, a piece of tissue was submerged within the beaker. After $10 \mathrm{~min}$, the tissue was removed, mounted on a slide in $\mathrm{dH}_{2} \mathrm{O}$ (at ambient temperature) to create a wet mount, and then sealed with a cover slip with VALAP.

\section{Sodium chloride treatments}

Solutions of $100 \mathrm{mM}, 400 \mathrm{mM}$ and $2 \mathrm{M} \mathrm{NaCl}$ (>99.5\% Purity; SIGMA-ALDRICH Inc., St. Louis, Missouri, USA) were prepared. Tissue was mounted on a slide, the appropriate solution was added to create a wet mount, and the cover glass was sealed on all sides with VALAP.

\section{Acid and base treatments}

For solutions of moderate $\mathrm{pH}(3 \mathrm{mM} \mathrm{HCl}, 30 \mathrm{mM}$ $\mathrm{NaOH}$ ), the solution was added to the slide before placing 
and then sealing the cover slip. For solutions that were strongly acidic or basic, respectively, $(12 \mathrm{M} \mathrm{HCl}, 1 \mathrm{M}$ $\mathrm{NaOH}$ ), the cover slip was sealed on two opposing sides, and the solution was added once the slide was mounted on the microscope. Observation ceased once cells were determined to be dead (no more than $6 \mathrm{~h}$ ). A video using leaf sheath tissue with the $30 \mathrm{mM} \mathrm{NaOH}$ treatment was used to provide a clearer image of the vesicles.

\section{Light microscopy, video and image acquisition, editing and time analysis}

Videos and images of epidermal, NPCD stage cells, cells which do not undergo developmental PCD, were taken using DIC optics on a Nikon 90i (Nikon Canada, Mississauga, Ontario, Canada) microscope fitted with a DXM 1200c digital camera. Data acquisition was made using NIS Elements AR 3.10 software (Nikon Canada, Mississauga, Ontario, Canada). Digital photographs were taken with a Nikon Coolpix L110 camera (Nikon Canada, Mississauga, Ontario, Canada). Image edits were made with Adobe Photoshop and Adobe Illustrator (Adobe Systems Inc., San Jose, California, USA). Video editing was made with Adobe Premier Pro CS5 (Adobe Systems Inc., San Jose, California, USA). All additional file videos were standardized to $1 \mathrm{~min}$ duration regardless of original duration length and this standardization accounts for differing playback speeds. The time for cell death to occur is represented as the mean \pm standard deviation and spans from the moment a given treatment was applied until tonoplast collapse or PM retraction were observed. Data are represented as the mean \pm standard deviation.

\section{Additional files}

\section{Additional file 1: Developmental PCD gradient within a single} areole over $\mathbf{3 0} \mathrm{min}$. NPCD stage cells (right) do not undergo PCD during leaf morphogenesis and contain anthocyanin pigmentation in the mesophyll. Cells within the EPCD and LPCD stages do not contain anthocyanin. Several of the nuclei are visible, including their nucleoli. Note the reduction in the number of chloroplasts in LPCD cells in comparison with EPCD cells. Large aggregates form in EPCD cells and are readily apparent in LPCD cells. TVS increase notably in EPCD cells but are less frequent in LPCD cells. Approximately 30 playback speed.

Additional file 2: Control NPCD cells. Untreated NPCD cells mounted in distilled water over a $6 \mathrm{~h}$ observation period. The cells show no obvious signs of stress and do not die within a $6 \mathrm{~h}$ period and thus serve as a control for comparison with the induced cell death treatments. Approximately 360x playback speed.

Additional file 3: NPCD cells treated at $45^{\circ} \mathrm{C}$ for $10 \mathrm{~min}$. Cells in this heat shock treatment largely resemble untreated NPCD cells. Nuclear displacement may be due to changes in vacuolar dimensions. TVS are visible and are denoted. No cell death occurs. Approximately 360X playback speed.

Additional file 4: NPCD cells treated at $55^{\circ} \mathrm{C}$ for $10 \mathrm{~min}$. Anthocyanin disappeared from the underlying mesophyll cells during the heat shock process. Increase in vesicle formation along periphery of cells occurs throughout the treatment. Tonoplast collapse and PM retraction from the cell wall occur simultaneously. Approximately $360 \times$ playback speed.
Additional file 5: NPCD cells treated with $100 \mathrm{mM} \mathrm{NaCl}$ solution. Large aggregates form in the central vacuole of the cells. TVS increase throughout the treatment. Chloroplast appearance changes throughout treatment to appear 'wrinkled'. The PM appears to remain intact throughout treatment and no retraction occurs. No cell death occurs. Approximately $360 \times$ playback speed.

Additional file 6: NPCD cells treated with $400 \mathrm{mM} \mathrm{NaCl}$ solution. Hechtian strands present between PM and cell wall. Note the plasmolyzed cells at the beginning. Chloroplasts appear to swell throughout the treatment while appearing 'wrinkled'. Tonoplast collapse and PM retraction occurs at cell death. Approximately $300 \times$ playback speed.

Additional file 7: NPCD cells treated with $2 \mathrm{M} \mathrm{NaCl}$ solution.

Plasmolysis occurs rapidly after contact with the solution. Hechtian strands are present between the PM and cell wall, but are not abundant. Note the spherical bodies that form before cell death. Throughout the process, anthocyanin pigmentation in the tissue slowly changes colour and becomes green as the cells die. Swelling occurs prior to tonoplast collapse and a dramatic retraction of the PM. Approximately 300x playback speed.

Additional file 8: NPCD cell treated with $12 \mathrm{M} \mathrm{HCl}$ solution. Cell death occurs extremely quickly due to the severity of the stressor. The pink colour from vacuolar anthocyanin does not disappear at the time of cell death in the presence of the low pH solution. Notable is the momentary swelling of the nucleoli immediately before nuclear condensation. Tonoplast collapse and PM retraction from the cell wall occur simultaneously. Approximately $1.25 \times$ playback speed.

Additional file 9: NCPD cells treated with $3 \mathrm{mM} \mathrm{HCl}$ solution. Note nuclear displacement may be due to changes in vacuolar dimensions. A slowdown of cytoplasmic streaming occurs and later there an increase in vesicle formation immediately before tonoplast collapse. Tonoplast collapse and nuclear condensation occur simultaneously. No PM retraction from the cell wall occurs. Approximately 180x playback speed.

Additional file 10: NPCD cells treated with $30 \mathrm{mM} \mathrm{NaOH}$ solution. An increase in vesicle formation occurs and they fuse with the vacuole before tonoplast collapse. Immediately prior to tonoplast collapse, a large amount of precipitates in the vacuole are visible. Note the swollen appearance of the chloroplasts. No PM retraction occurs. Approximately $45 \times$ playback speed.

Additional file 11: Leaf sheath tissue treated with $30 \mathrm{mM} \mathrm{NaOH}$ solution. Following exposure to $30 \mathrm{mM} \mathrm{NaOH}$ there is an abundance of vesicles within cells. Chloroplasts are visible within vesicles, which fuse with the central vacuole immediately prior to tonoplast collapse. No PM retraction is observed. Approximately $25 \times$ playback speed.

Additional file 12: NPCD cells treated with $1 \mathrm{M} \mathrm{NaOH}$ solution. An increased in vesicle formation occurs, and later the vesicles fuse to the central vacuole immediately before tonoplast collapse. Prior to cell death there is a dramatic change in colour due to the effect of $\mathrm{NaOH}$ on anthocyanin in the underlying mesophyll. Also, nuclei disappeared and large amounts of precipitates are present in the vacuole immediately before tonoplast collapse. Note the swollen appearance of the chloroplasts. No PM retraction occurs.

Approximately $2.5 \times$ playback speed.

\section{Abbreviations}

EPCD: Early programmed cell death; LPCD: Late programmed cell death; NPCD: Non-programmed cell death; PCD: Programmed cell death; PM: Plasma membrane; ROS: Reactive oxygen species; TVS: Transvacuolar strands.

\section{Competing interests}

The authors declare that they have no competing interests.

\section{Authors' contributions}

AND carried out all whole plant experiments and selected $\mathrm{NaCl}$, acid and base long-term imaging, video and figure editing, in addition to all experimental aspects involving leaf sheath tissue. TSW carried out experiments including: all heat long-term imaging, $\mathrm{NaCl}$ long-term imaging, selected acid and base long-term imaging, selected video and image editing. TSW and AND 
wrote the first draft of the manuscript, while AND edited the final manuscript and completed all requested revisions. AHLANG conceived the study, participated in its design and coordination, edited the manuscript revisions, and supervised all experimental work. All authors read and approved the final manuscript.

\section{Acknowledgements}

The authors greatly acknowledge Jaime Wertman (Department of Pharmacology, Dalhousie University) for critical review of this MS. The authors thank the National Sciences and Engineering Research Council of Canada (NSERC) and the Killam Trusts for PhD. funding for AND. The authors also acknowledge the Sarah Lawson Research Scholarship (Dalhousie University) for funding TSW. Lastly, thank you to the Canadian Foundation for Innovation (CFI) for the Leaders Opportunity Fund along with NSERC for discovery and equipment grants for AHLANG.

Received: 29 July 2014 Accepted: 16 December 2014

Published online: 30 December 2014

\section{References}

1. Jan N, Mahboob-ul-Hussain, Andrabi Kl: Programmed cell death or apoptosis: Do animals and plants share anything in common. Biotechnol Mol Biol Rev 2008, 3:111-126.

2. Jones AM: Programmed cell death in development and defense. Plant Physiol 2001, 125:94-7.

3. Lord CEN, Gunawardena AHLAN: Programmed cell death in C. elegans, mammals and plants. Eur J Cell Biol 2012, 91:603-13.

4. Fuchs $Y$, Steller H: Programmed cell death in animal development and disease. Cell 2011, 147:742-58.

5. Gunawardena AHLAN: Programmed cell death and tissue remodelling in plants. J Exp Bot 2008, 59:445-51.

6. Noodén LD (Ed): Plant Cell Death: Processes. Academic Press; 2003:392.

7. Fukuda $\mathrm{H}$ : Programmed cell death of tracheary elements as a paradigm in plants. Plant Mol Biol 2000, 44:245-53.

8. Kroemer G, El-Deiry WS, Golstein P, Peter ME, Vaux D, Vandenabeele P, Zhivotovsky B, Blagosklonny MV, Malorni W, Knight RA, Piacentini M, Nagata S, Melino G: Classification of cell death: recommendations of the nomenclature committee on cell death. Cell Death Differ 2005, 12:1463-7.

9. Kerr JFR, Wyllie AH, Currie AR: Apoptosis : a basic biological phenomenon with wide-ranging implication in tissue kinetics. Br J Cancer 1972, 26:239-57.

10. Kroemer G, Galluzzi L, Vandenabeele P, Abrams J, Alnemri ES, Baehrecke EH, Blagosklonny MV, El-Deiry WS, Golstein P, Green DR, Hengartner M, Knight RA, Kumar S, Lipton SA, Malorni W, Nuñez G, Peter ME, Tschopp J, Yuan J, Piacentini M, Zhivotovsky B, Melino G: Classification of cell death: recommendations of the nomenclature committee on cell death 2009. Cell Death Differ 2009, 16:3-11.

11. Van Doorn WG, Papini A: Ultrastructure of autophagy in plant cellspdf. Autophagy 2013, 9:1922-36.

12. Green: Means to an End: Apoptosis and Other Cell Death Mechanisms. Cold Spring Harbor Laboratory Press; 2011.

13. Van Doorn WG, Woltering EJ: Many ways to exit? cell death categories in plants. Trends Plant Sci 2005, 10:117-22.

14. Reape TJ, McCabe PF: Apoptotic-like programmed cell death in plants. New Phytol 2008, 180:13-26.

15. Reape TJ, McCabe PF: Commentary: the cellular condensation of dying plant cells: programmed retraction or necrotic collapse? Plant Sci 2013, 207:135-9.

16. Van Doorn WG, Beers EP, Dangl JL, Franklin-Tong VE, Gallois P, Hara-Nishimura I, Jones AM, Kawai-Yamada M, Lam E, Mundy J, Petersen M, Smertenko A, Taliansky M, Van Breusegem F, Wolpert T, Woltering E, Zhivotovsky B, Bozhkov PV: Morphological classification of plant cell deaths. Cell Death Differ 2011, 18:1241-6.

17. Van Doorn WG: Classes of programmed cell death in plants, compared to those in animals. J Exp Bot 2011, 62:4749-61.

18. Van Bruggen HV: Monograph of the genus Aponogeton (Aponogetonaceae). Bibl Bot 1985, 33:1-76.

19. Tomlinson PB: VII Helobiae (Alismatidae). In Anatomy of the Monocotyledons. Edited by Metcalfe CR. Oxford: Clarendon Press; 1982 p.198-225.
20. Gunawardena AHLAN, Greenwood JS, Dengler NG: Progammed cell death remodels lace plant leaf shape during development. Plant Cell 2004, 16(January):60-73.

21. Wright $H$, van Doorn WG, Gunawardena AHLAN: In vivo study of developmental programmed cell death using the lace plant (aponogeton madagascariensis; aponogetonaceae) leaf model system. Am J Bot 2009, 96:865-76.

22. Wertman J, Lord CEN, Dauphinee AN, Gunawardena AHLAN: The pathway of cell dismantling during programmed cell death in lace plant (aponogeton madagascariensis) leaves. BMC Plant Biol 2012, 12:1-16.

23. Lord CEN, Gunawardena AHLAN: Environmentally induced programmed cell death in leaf protoplasts of aponogeton madagascariensis. Planta 2011, 233:407-21.

24. Lord CEN, Wertman JN, Lane S, Gunawardena AHLAN: Do mitochondria play a role in remodelling lace plant leaves during programmed cell death? BMC Plant Biol 2011, 11:1-17.

25. Vacca RA, de Pinto MC, Valenti D, Passarella S, Marra E, De Gara L: Production of reactive oxygen species, alteration of cytosolic ascorbate peroxidase, and impairment of mitochondrial metabolism are early events in heat shock-induced programmed cell death in tobacco bright-yellow 2 cells. Plant Physiol 2004, 134:1100-12.

26. Ahmed J, Shivhare US, Raghavan GSV: Thermal degradation kinetics of anthocyanin and visual colour of plum puree. Eur Food Res Technol 2004, 218:525-8.

27. Knight H: Calcium signaling during abiotic stress in plants. Int Rev Cytol 1999, 195:269-324.

28. Mansour MMF, Salama KHA: Cellular basis of salinity tolerance in plants. Environ Exp Bot 2004, 52:113-22.

29. Khavari-Nejad RA, Mostofi Y: Effects of $\mathrm{NaCl}$ on photosynthetic pigments, saccharides, and chloroplast ultrastructure in leaves of tomato cultivars. Photosynthetica 1998, 35:151-4.

30. Fidalgo F, Santos A, Santos I, Salema R: Effects of long-term salt stress on antioxidant defence systems, leaf water relations and chloroplast ultrastructure of potato plants. Ann Appl Biol 2004, 145:185-92.

31. Parida AK, Das AB: Salt tolerance and salinity effects on plants: a review. Ecotoxicol Environ Saf 2005, 60:324-49.

32. Mimura T, Kura-Hotta M, Tsujimura T, Ohnishi M, Miura M, Okazaki Y, Mimura M, Maeshima M, Washitani-Nemoto S: Rapid increase of vacuolar volume in response to salt stress. Planta 2003, 216:397-402.

33. Liu Y, Xiong Y, Bassham DC: Autophagy is required for tolerance of drought and salt stress in plants. Autophagy 2009, 5:954-63.

34. Lang I, Barton DA, Overall RL: Membrane-wall attachments in plasmolysed plant cells. Protoplasma 2004, 224:231-43.

35. Mittler R: Abiotic stress, the field environment and stress combination Trends Plant Sci 2006, 11:15-9.

36. Minina EA, Bozhkov PV, Hofius D: Autophagy as initiator or executioner of cell death. Trends Plant Sci 2014, 19:692-7.

\section{Submit your next manuscript to BioMed Central and take full advantage of:}

- Convenient online submission

- Thorough peer review

- No space constraints or color figure charges

- Immediate publication on acceptance

- Inclusion in PubMed, CAS, Scopus and Google Scholar

- Research which is freely available for redistribution 